\title{
Content Analysis of Spiritual Life in Contemporary USA, India, and China
}

\author{
Elsa Lau ${ }^{1, *}$, Clayton McClintock ${ }^{1}$, Marianna Graziosi ${ }^{2,3}{ }^{\mathbb{D}}$, Ashritha Nakkana ${ }^{1}$, Albert Garcia ${ }^{1}$ \\ and Lisa Miller ${ }^{1}$ \\ 1 Department of Counseling and Clinical Psychology, Teachers College, Columbia University, New York, \\ NY 10027, USA; chm2130@tc.columbia.edu (C.M.); an2765@tc.columbia.edu (A.N.); \\ g3620@tc.columbia.edu (A.G.); amillera@exchange.tc.columbia.edu (L.M.) \\ 2 Positive Psychology Center, University of Pennsylvania, Philadelphia, PA 19104, USA; \\ marigraz@sas.upenn.edu \\ 3 Clinical Psychology Department, Hofstra University, Hempstead, NY 11549, USA \\ * Correspondence: el2661@tc.columbia.edu
}

Received: 16 May 2020; Accepted: 8 June 2020; Published: 11 June 2020

\begin{abstract}
This study investigates the lived-experience of spiritual life in contemporary USA, India, and China. A qualitative coding frame was constructed based on participant responses to open-ended questions regarding spirituality. Qualitative analysis was facilitated by the use of Dedoose, a mixed methods software. The exploratory approach of this study takes on a cross-culturally comparative lens, and has two primary questions: (1) What are the universal aspects of lived spirituality across cultures, and (2) How does culture shape spiritual experience (e.g., typology and prevalence)? A total of 6112 participants ( $41 \%$ women, mean age of 29 years, range 18-75 years) were recruited, and analysis was conducted on a subset of 900 participants. The primary thematic categories derived by content analysis included religion (religious traditions, religious conversion, religious professionals, religious figures "theophany," and religious forces "heirophany"), contemplative practice (meditation, mindful movement, prayer, and rituals), ancestors (ancestral worship, dreams about ancestors, and general mention of ancestors), natural world (animals, and nature), and metaphysical phenomena. Metaphysical categories were further parsed apart to include extrasensory perception (telepathy, clairvoyance, precognition, realistic dreams, and intuitive impressions), psychokinesis, survival hypothesis (near death experiences, out of body experiences, and apparitional experiences), and faith and energy healing (recovery/remission of illness, and spiritual practitioners). Explanatory factors for similarities and differences across groups, and the origins of spirituality, are discussed.
\end{abstract}

Keywords: spirituality; religious experience; culture; metaphysical phenomena; qualitative

\section{Introduction}

\section{Universal Spirituality}

Research indicates that spirituality and religion are two different constructs. Spirituality is an innate part of all individuals according to twin studies which show $30 \%$ of the human capacity for spirituality is due to broad heritability (Kendler et al. 1997). Spirituality is a way of perception and connection with the life force, the greater Universe, and the transcendent in daily life. Religion is taught and is over $90 \%$ socialized (Kendler et al. 1999). Religion is a form of expression, a system of ritual, teachings and meaning that embraces our natural spirituality (Zinnbauer et al. 1999). Spirituality is innate and religion is socialized. Religion can foster a natural spirituality; however, spirituality can be fostered in other ways. 
The current body of literature on universal aspects of spirituality examines definitions, theories, and applications (de Jager Meezenbroek et al. 2012). Several meta-analyses have identified spirituality's positive relationship with quality of life (Sawatzky et al. 2005), well-being in the context of palliative care and hospice (Edwards et al. 2010), and physical health (Jim et al. 2015). The research on spirituality in religion, health care, personal growth, and cross-cultural contexts, utilizes a wide range of terminology which may imply a diversity of non-standardized definitions within the field (Moberg 2002). A review of 73 studies offered potential core definitions for spirituality, including connectedness, transcendence, existential reality, meaning, purpose, sacredness, yoga, meditation, self-awareness, and religious practice (Chiu et al. 2004).

Meditation has been proposed to be a cross-culturally salient pathway to spiritual development (Kristeller and Jordan 2017), as well as the arts (Mooney and Timmins 2007). Spirituality may also be a fundamental component of personality across cultural groups (Rican and Janosova 2010), or a cultural adaptation of the personality traits of agreeableness and conscientiousness (Saroglou 2010). Meditation, healing groups and twelve-step programs are reported pathways to the sacred which can transform and enhance the human experience (Zinnbauer et al. 1999). A deepened, more personalized sense of spirituality may have the potential to bring greater well-being to diverse individuals and communities.

\section{Spiritual Life Across Three Countries}

\subsection{USA: Polarization of Religion and Spirituality}

Increasing interest in the topic of religion and spirituality in American psychology has fueled research efforts to characterize spiritual life in America. Though the racially and religiously heterogeneous makeup of the American population complicates the search for definitive types of spiritual experience, a close examination of relevant literature provides trends. There is a growing polarization between the concept of religion and spirituality, such that the term religion is increasingly becoming associated with "institutional, formal, outward, doctrinal, authoritarian, and inhibiting individual expression," while spirituality has become associated with a more personal side of religion, involving "individual, subjective, emotional, inward, unsystematic, and self-expression" (Hill and Pargament 2008). This parallels the trend towards secularization in the U.S., where a growing number of individuals profess no religious affiliation but consider themselves spiritual or religious (Bengtson et al. 2015). This phenomenon called "new age spirituality" has been described as encompassing three main facets, including a mystical idea of one's inner self and divine nature, an emphasis on harmony throughout the world rather than conflict, and an approach to truth that requires subjective experience rather than objective and analytical methods of modern science (Houtman et al. 2009).

Spiritual experiences in America can also be understood through instrument-formation. For example, The Daily Spiritual Experience Scale assesses the extent to which an individual addresses their ultimate questions about life-meaning, perceives the transcendent in daily life, and uses spiritual beliefs to overcome physical or emotional difficulties (Underwood and Teresi 2002). Another scale, The Spiritual Assessment Scale, conceptualizes spirituality as a phenomenon with four critical attributes, including purpose and meaning in life, inner resources, unifying interconnectedness, and transcendence (Delaney 2005). Based on the conceptualizations of spirituality evident in these scales developed by and tested on U.S. samples, it can be surmised that U.S. spirituality generally focuses on personal interaction with the transcendent and deriving a sense of purpose and meaning from spiritual interactions, and this manifests most robustly in coping with hardship (Skaggs and Barron 2006).

\subsection{India: Secularism and Spirituality}

Similar to Western counterparts, spirituality in India transcends institutionalized religion and authority of priestly lineages and monastic institutions (Van der Veer 2009). Gandhi has played a significant role in transforming secularism and state neutrality into an aspect of Indian spirituality, 
which exemplifies the continuity between colonial and postcolonial India (Van der Veer 2009). Neoliberal capitalism has become the backdrop to workplace spirituality, emphasizing meditation and practices that enhance daily living in a manner that suits the lifestyles of young urban professionals (Van der Veer 2009).

The research on psychology and Hinduism describes spirituality in India as placing emphasis upon transcendence and universal connectedness (Aurobindo 1919, p. 2). This belief in a unitive nature of life is called universality (Piedmont and Leach 2002). For example, in Hinduism, Brahman is the ultimate reality underlying all existence, and a core underpinning of this popular religion lies in the union of individual identity with Brahman (Hanna and Green 2004). Indian psychology also recognizes paranormal aspects of human experience and provides plausible explanations for these phenomena (Dalal and Misra 2010). In some circumstances, spiritual ecstasies are not considered abnormal in Indian society, and traditionally, individuals who displayed altered mental states were not treated for mental disorders (Bhawuk 2003).

A few studies have developed scales to measure spirituality in Indian samples. Piedmont and Leach (2002) administered the Spiritual Transcendence Scale developed by Piedmont (1999) to a sample of 369 Indian undergraduate students. Prayer Fulfillment (positive feelings resulting from personal encounters with a transcendent being) and Universality (unitive nature of life), showed moderate levels of reliability, while Connectedness (connection with other individuals across generations and groups) showed a low level of reliability. Gaur and Sharma (2014) developed a novel Spiritual Health Assessment Scale and found three domains of spirituality emerged within another Indian sample, including self-development, self-actualization and self-realization.

\subsection{China: Religious Revival and Syncretism}

China has witnessed a rapid revival of religious faith since 1979 (Liang 2012; Lizhu 2003; Madsen 2011). Present day diverse practices and beliefs come from official and unofficial religions, as designated by the government, as well as folk religion (Harrell 1977; Harrell 1979). Religious revival for ethnic minorities like Uighurs and Tibetans has been paralleled by a broad cultural renaissance (Madsen 2011). Official statistics in 2003 have indicated that upwards of 200 million believers reside in China, and this large group has expanded in response to several factors. This includes the dissolution of the ban on freedom of worship, and emergence of political and economic reforms leading to social uncertainties (Lai 2005). In the 21st century, China's Buddhist diplomacy has emerged as a potential buffer and moral foundation against the rapidly changing economy and Christian movement. Buddhism in this modern context may offer a new possibility of social harmony amidst globalization by increasing diversity of thought in China (Angelskår 2013).

Modernization has also contributed to religious re-composition in China. As a result, spiritual independence has gradually increased, paralleling the emergence of autonomous individualism (Ji 2006). Chinese spiritual beliefs have somewhat liberalized and diversified over the last 30 years (Zhang et al. 2011). The emerging presence of spiritual and religious syncretism in China may facilitate more harmonious coexistence of traditional and nontraditional beliefs (Baird 2004). This re-emergence and reformation of old tradition and ideologies of a new typology may be linked to an underlying thirst for knowledge of the spirit (Goossaert and Palmer 2011).

Zhang et al. (2011) found that the content of Chinese youth and young adults' spiritual beliefs included religious beliefs, soul beliefs, spiritual transcendence beliefs, inner power beliefs, social beliefs, and practical beliefs. In this study, $31 \%$ emphasized spiritual transcendence and believed in a spiritual world beyond religion (Zhang et al. 2011). Notably, atheism is the established official belief system, which may at least partially explain why $40 \%$ of university students from Beijing, China's largest city, reported strong uncertainty about religious beliefs and their importance (Zhang et al. 2011). 


\section{Aims of Study}

This study investigates the lived experience of spirituality in contemporary USA, India, and China. In this study, culture was defined as geographic and/or ethnically clustered groups of individuals with broad relative commonalities in socio-cultural histories. Religion was considered as an aspect of spirituality and spiritual life. A qualitative coding frame was formulated based on participant responses to open-ended questions regarding spirituality. The exploratory approach of this study takes on a cross-culturally comparative lens, and has two primary areas of inquiry, specifically: (1) What are the universal aspects of lived spirituality, and (2) How does culture shape spiritual experience (e.g., typology and prevalence)?

\section{Method}

\subsection{Participants}

From June 2014 to February 2015, 6112 participants (41\% women, mean age $=29$ years, range 18-75 years) were recruited from equivalent crowdsourcing websites: Mturk.com for residents in the US $(\mathrm{N}=1633)$ and India $(\mathrm{N}=1141)$, and Zhubajie.com for residents in China $(\mathrm{N}=3338)$ (see Table 1). Participants were reimbursed $\$ 6$ or its equivalent after full completion of the qualitative and demographic questionnaire. The online questionnaire consisted of a number of widely used spiritual, clinical, and psychological instruments, as well as socio-demographic and open-ended qualitative questions (this study focuses on the qualitative data). This study was approved by the Institutional Review Board of Teachers College, Columbia University, and informed consent was obtained from participants before inclusion in the study.

Table 1. Demographics.

\begin{tabular}{|c|c|c|c|}
\hline Characteristic & China & India & USA \\
\hline Age & \multicolumn{3}{|c|}{$\mathrm{M}=29$ years, Range $18-75$ year } \\
\hline Gender & $\%$ & $\%$ & $\%$ \\
\hline Female & 40.5 & 62.3 & 45.6 \\
\hline Male & 59.3 & 37.7 & 54.4 \\
\hline \multicolumn{4}{|l|}{ Marital Status } \\
\hline Married & 25.2 & 51.3 & 38.6 \\
\hline Widowed/divorced & 1.3 & 2 & 11.1 \\
\hline Single never married & 73.3 & 46.1 & 50.2 \\
\hline \multicolumn{4}{|l|}{ Children } \\
\hline Yes & 17 & 41.9 & 42.3 \\
\hline No & 82.7 & 57.6 & 57.7 \\
\hline \multicolumn{4}{|l|}{ Sexual Orientation } \\
\hline Straight & 94.4 & 80.6 & 89.4 \\
\hline Gay/Lesbian & 1.5 & 0 & 3.3 \\
\hline Bisexual & 1.8 & 11.5 & 5.5 \\
\hline \multicolumn{4}{|l|}{ Education Level } \\
\hline Some high school/High school degree & 6.6 & 2.6 & 14 \\
\hline Some college/Associate degree & 44.8 & 9.4 & 39.3 \\
\hline Undergraduate degree & 42 & 46.6 & 33.8 \\
\hline Graduate degree & 6.4 & 40.3 & 12.8 \\
\hline \multicolumn{4}{|l|}{ Estimated Personal Income } \\
\hline Above 75 th percentile & 6.9 & 24.6 & 6 \\
\hline Between 50-75th percentile & 14.2 & 24.1 & 15.3 \\
\hline Between $25-50$ th percentile & 40.2 & 22.5 & 26.0 \\
\hline Below 25th percentile & 38.4 & 27.7 & 52.1 \\
\hline \multicolumn{4}{|l|}{ Environment prior to age 18} \\
\hline Urban & 20.6 & 44.5 & 24.1 \\
\hline Suburban & 13 & 22.5 & 50.1 \\
\hline Rural & 41 & 23.0 & 21.3 \\
\hline Mixed & 25.4 & 9.4 & 4.5 \\
\hline
\end{tabular}

Note. Demographics of 6112 participants recruited on crowdsourcing platforms. 


\subsection{Measures}

Nine qualitative multi-part questions were included as two separate blocks in the beginning and middle of the questionnaire. Questions included: (1) How do you define religion? (2) How do you define spirituality? (3) Please tell us the story of your most significant spiritual or religious experience. What led up to it? How did it affect the way you live? How did it change your view of reality or sense of purpose? (4) If you have ever had an experience of any of the following, would you please tell us your story? (A healing through prayer. A prophetic dream. A visitation by an ancestor, angel, or other sacred being. A strongly felt sense of oneness and connection. An important synchronicity. Any other surprising or meaningful spiritual experience that you have not yet shared.) (5) Who have been the most significant figures in your own spiritual or religious growth? Please tell us about the development of one of these relationships. (6) Please use this space to elaborate in your own words on your spiritual life story. (7) How is spirituality or religion a positive presence in your everyday life? How has that changed over time? Have there been times where spirituality or religion has influenced you in a negative way? (8) Has spirituality or religion ever helped you through times of suffering? If so, please tell us the story. (9) Do you believe that there is something essentially "you" that will live on after you die? If so, was this essence of "you" something that was present before you were born?

\subsection{Procedure}

The survey was provided in English for the US and India participants, and the China survey was translated into Chinese. The Chinese translation process followed common and recommended procedures for instrument adaptation (Squires et al. 2013). The translation committee consisted of five bilingual translators. To establish conceptual equivalence of the original instruments, the Chinese version was back-translated into English by unique translators, and was compared to the original English survey by the entire translation committee. A few terms that required clarification were discussed, and modifications were applied to adjust for minor conceptual discrepancies encountered during the translation and back-translation process.

\subsection{Data Analysis}

Across the spectrum of qualitative analysis described by Vaismoradi and colleagues (Vaismoradi et al. 2013) ranging from thematic analysis to content analysis, the approach used in this study primarily focuses on a content analysis approach. Due to the limited research on cross-cultural spirituality in larger samples, the aim was to identify lived experiences or manifestations of spirituality for adults across the US, India, and China. The qualitative analyses were informed by the inductive process of grounded theory, which utilizes a bottom-up data-driven approach (Braun and Clarke 2006; Charmaz 2011). Stages of analysis included coding participants from each country to attain theme saturation, exploring coding for interpretative bias and reliability, ensuring parsimony in content categories, and establishing hierarchical categories to organize into a code frame.

To develop a code frame, 100 participants were randomly selected from each country and coded with the assistance of Dedoose, a mixed-methods qualitative software. All potential themes were parsed out for each open-ended question by committee members until theme saturation was reached across raters during the open coding phase. To ensure inter-rater reliability during this stage of analysis, committee members reviewed data independently. Themes were subsequently compared and consolidated, and a hierarchical coding-frame was developed. During the selective coding phase, the coding-frame was applied to 600 participants. Lastly, representative narratives which best illustrate each theme were determined through independent and subsequent committee review.

\section{Results}

In the US sample, $61 \%$ endorsed a religious denomination and $48 \%$ identified as Christian. In the India sample, $96 \%$ endorsed a religious denomination, with $63 \%$ identifying as Hindu. In the China 
sample, 57\% endorsed a religious denomination, with 36\% identifying as Buddhist (see Figure 1 for further detail). Overall, religion was associated with both positive and negative attributes. Across all three countries, participants often described religion as a formal set of rules, oftentimes dualistic and dogmatic, a system of faith and worship, a frame work of life/the world/the universe, an organized cultural system of world views, teachings based on religious texts, ideologies on how people should behave to create a harmonious society, a guidance system, morality, hierarchical groups, powerful institutions that can exploit the innocent, a belief in divine beings, altruism and good actions, objectification, superstition, faith, and commonly a path to spirituality or something that strengthens spirituality.

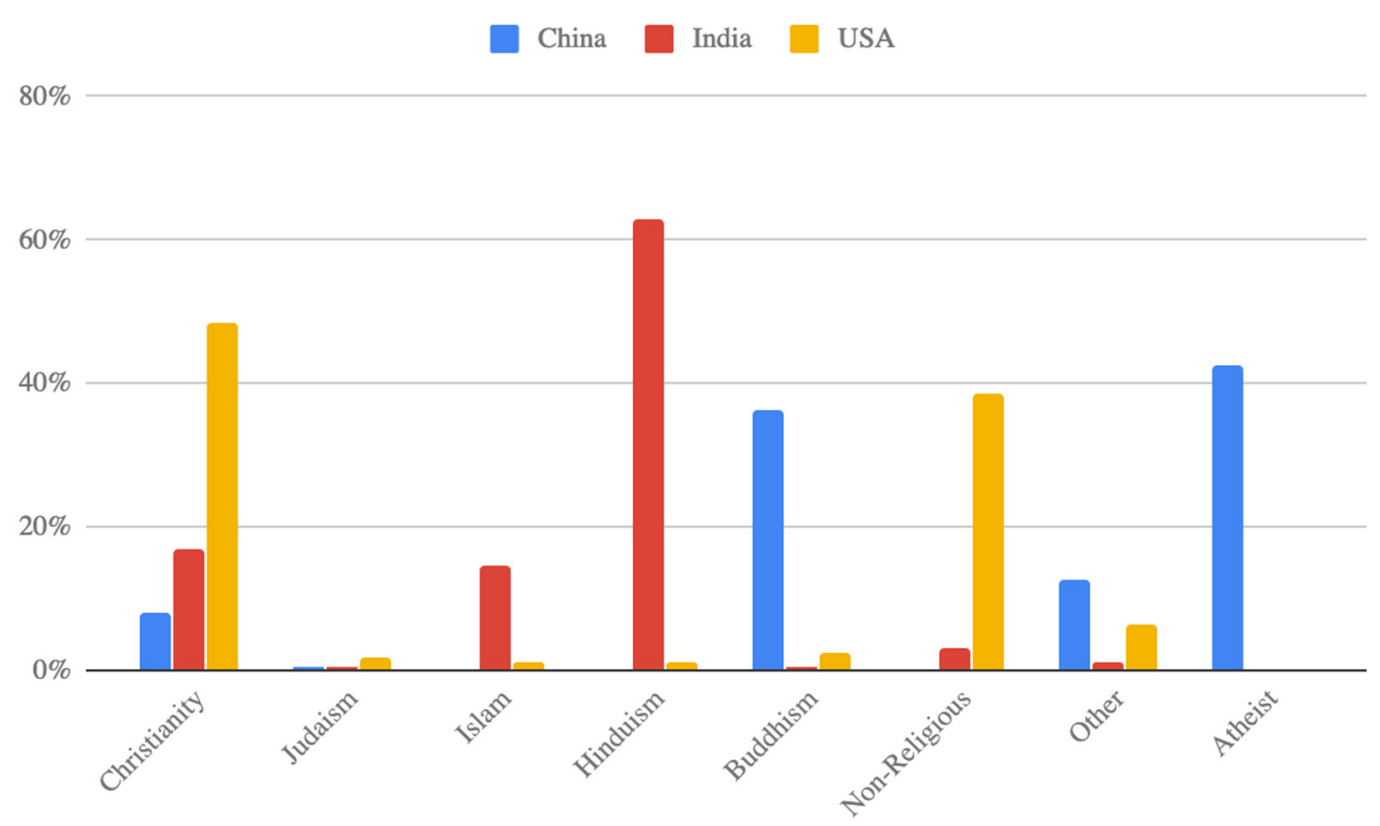

Figure 1. Religious affiliation.

Perceived importance of spiritual life varied by country, with over $20 \%$ in the US, $50 \%$ in India, and $5 \%$ in China reporting spirituality as highly important (see Figure 2 for further detail). Spirituality was often described as a positive and personalized process. Across all three countries, participants frequently described spirituality as the following: meaning-making, reflection on life and death, intuition, a personal experience of God, an innate process, a human capacity, individual purpose, devotion, integration of religious ideals, focus on non-material world, personal relationship with god, faith in God or a higher power that results in transformation, a search for transformation, something immeasurable by modern science, enlightenment, intelligence, religious practices, something that is both innate and cultivated through reflection and application of moral/ethical virtues, and is associated with non-material and metaphysical experiences.

Primary thematic categories included religion (religious traditions, religious conversion, religious professionals, religious figures "theophany," and religious forces "heirophany,") contemplative practice (meditation, mindful movement, prayer, and rituals), ancestors (ancestral worship, dreams about ancestors, and ancestors discussed), natural world (animals, and nature), and metaphysical phenomena (see Table 2 and Appendix A). Metaphysical categories were further parsed apart with reference to nomenclature established in the field of paranormal psychology (Irwin and Watt 2007), which provided parsimonious terminology and higher-order classification of data-driven categories. These include extrasensory perception (telepathy, clairvoyance, precognition, realistic dreams, and intuitive impressions), psychokinesis, survival hypothesis (near death experiences, out of body experiences, and apparitional experiences), and faith and energy healing (recovery/remission of illness, and spiritual practitioners). The faith and energy healing category combines "psychic healing" described by 
Irwin and Watt (2007), and Levin's (2011) typologies of culturally and historically distinct groups of energy healers with unique cultural lineages. Chi-square analyses of the qualitative frequencies revealed all broad categories (contemplative practice, ancestors, and natural world) to be significantly different between countries ( $p=0.001$ ), with the metaphysical category being significantly different to a relatively lesser degree $(p=0.005)$.

Table 2. Rates of Codes Occurrence by Country (Percent).

\begin{tabular}{|c|c|c|c|c|}
\hline Theme & Subthemes & USA & India & China \\
\hline \multirow{6}{*}{ Religion } & & 83 & 86 & 58 \\
\hline & Traditional Religious Practices & 77 & 61 & 38 \\
\hline & Religious Conversion & 23 & 7 & 2 \\
\hline & Religious Professionals & 16 & 20 & 7 \\
\hline & Theophany (religious figure such as Jesus) & 48 & 70 & 36 \\
\hline & Hierophany (religious force such as holy spirit) & 6 & 9 & 5 \\
\hline \multirow{5}{*}{ Contemplative Practice } & & 60 & 72 & 51 \\
\hline & Meditation & 11 & 15 & 4 \\
\hline & Mind-body Practices & 4 & 9 & 2 \\
\hline & Prayer & 52 & 66 & 48 \\
\hline & Rituals/Ceremonies & 6 & 8 & 10 \\
\hline \multirow{3}{*}{ Natural World } & & 29 & 5 & 19 \\
\hline & Nature & 25 & 3 & 12 \\
\hline & Animals & 8 & 3 & 10 \\
\hline \multirow{4}{*}{ Ancestors } & & 32 & 18 & 33 \\
\hline & Ancestor Mentioned & 22 & 12 & 19 \\
\hline & Ancestral Worship & 0 & 1 & 3 \\
\hline & Ancestor Dream & 15 & 8 & 17 \\
\hline \multirow{15}{*}{ Metaphysical Phenomena } & & 75 & 64 & 69 \\
\hline & Extrasensory Perception & 51 & 39 & 56 \\
\hline & Telepathy & 5 & 2 & 6 \\
\hline & Clairvoyance & 13 & 5 & 6 \\
\hline & Precognition & 2 & 1 & 2 \\
\hline & Realistic Dreams & 25 & 18 & 34 \\
\hline & Intuitive Impressions & 27 & 21 & 32 \\
\hline & Psychokinesis & 7 & 7 & 4 \\
\hline & Survival Hypothesis & 30 & 21 & 22 \\
\hline & Near Death Experience & 1 & 1 & 0 \\
\hline & Out of Body Experience & 2 & 4 & 2 \\
\hline & Apparitional Experience & 27 & 16 & 20 \\
\hline & Faith/Energy Healing & 18 & 29 & 21 \\
\hline & Recovery/Remission of Illness & 17 & 23 & 18 \\
\hline & Spiritual Practitioners & 1 & 7 & 6 \\
\hline
\end{tabular}




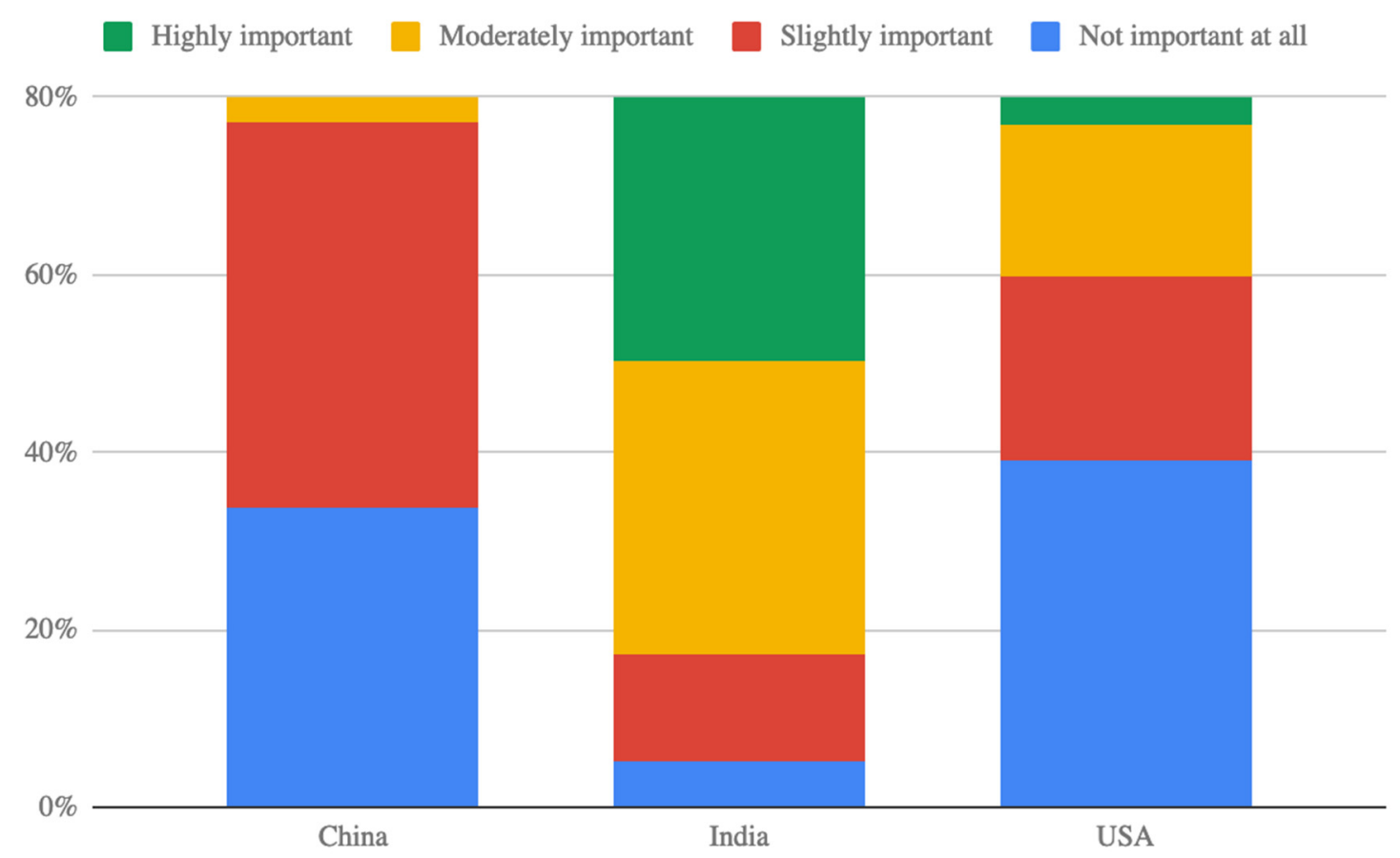

Figure 2. Perceived importance of spirituality.

\section{Discussion}

The aim of this study was to identify categories of lived spirituality in contemporary US, India, and China using qualitative analysis over free-response narratives. These three countries carry unique cultural and historical contexts which shape current religious practices, spiritual experiences, and language repertoire in describing spiritual life. Despite these differences, similarities emerged through the data-driven inductive analyses, and is strikingly seen in the concomitant categories. Metaphysical phenomena were actively reported across countries, despite varying rates of religious, non-religious, and atheistic identification across countries. The absence of the parameters of quantitative scales, which sometimes implicitly carry cultural specificity, may have played a role in revealing common facets of spirituality. As such, this qualitative study served to generate conceptual insight into the possibility of shared and specific spiritual experience across three diverse cultural groups.

\subsection{Commonalities in Spiritual Life}

Religion was commonly mentioned in China (58\%), India (86\%) and the US (83\%), with emphasis on religious figures or "theophany" (e.g., Jesus and Buddha), although a substantial subset described religious forces or "heirophany" (e.g., the Holy Spirit or the Tao). Religious professionals were more frequently mentioned in India and the US relative to China, indicating that religious authorities may have a lesser degree of influence on spiritual life in China. Contemplative practice was also common in all three countries (51-72\%), and frequently occurred in the form of prayer. Participants from India and the US were equally likely to report having a meditation practice, though mind-body practices such as yoga were more prominent in India, where the original practice of yoga was developed (Newcombe 2009). The natural world was reported in both China (19\%) and the US (29\%), while seldomly mentioned in India (5\%). A surprising commonality among US and China participants was the role of ancestors in spiritual life. In both countries, around 32 percent of participants described ancestors as important mentors on their spiritual path, and as lively (albeit disembodied) spirits or forces after death. Additionally, in both countries, ancestors often appeared in dreams as omens portending death. Lastly, 64 to 75 percent of participants in each country described experiences of metaphysical phenomena. While the prevalence of subtypes varied by country, the transcendent non-material dimension to spiritual life was clearly active and readily reported across countries. 
The broad convergence and pattern of response in descriptions of spiritual life suggests that, while spiritual expression is culturally molded, it is not culturally constrained. A study involving the quantitative data from this sample (McClintock et al. 2016) used factor analysis and confirmatory ESEM to identify five dimensions of spiritual experience which included (1) love, in relationships and as a sacred reality (2) interconnectedness with other beings, (3) altruism, (4) contemplative practice, and (5) religious and spiritual reflection. In our current study, the prevalent theme of ancestors and metaphysical phenomena provides support for the dimensions of love and interconnectedness. The literature on spirituality supports the notion that spirituality is an innate feature of the human experience (Kendler et al. 1997; Muller 2008; Newberg and Newberg 2008). Neuroscience offers evidence of biological correlates of spiritual experience (Newberg et al. 2003; Miller et al. 2014; Miller et al. 2019), which strengthens the case for an innate spirituality, with expression that is simply shaped by culture.

The Western emphasis on secular-materialism seems to have found its way into Eastern cultures (Ager and Ager 2011; Ger and Belk 1995; Podoshen et al. 2011), which is potentially an artifact of globalization. Religious faith traditions and non-secularism are increasingly seen as less "real" or valuable relative to a secular worldview, which emphasizes the supremacy of science and the material world. As such, the transcendent relationship with the world of spirit, adherence to a faith tradition, and experiences of metaphysical phenomena may be seen as less socially desirable than the secular materialist view for some participants. Several participants were apologetic for sounding "too religious." Overall, the relative similarities in code frequency and categories may give support for underlying core features of spiritual life. Nuanced differences were identified and may shed light on the cultural forces shaping lived spirituality.

\subsection{Differences in Spiritual Life}

While religion appeared in the narratives from all three countries, religious conversion was more prevalent in the US (23\%), relative to China $(2 \%)$ and India ( $7 \%)$. Although there were relatively high reports of religion across countries, participants in India made more references to religious figures $(70 \%)$ compared to the US (48\%) and China (30\%). Contemplative practice was reported by participants in all three countries (51-72\%), but references to the experience of prayer occurred more often in India. While the natural world, which includes being in nature and with animals, was discussed by participants from both China (19\%) and the US (29\%); natural environments were much more readily described as a setting for spiritual transformation in the US. Mention of ancestors was common in China and the US; however, there were some key differences. In China ancestors were commonly associated with ancestral worship, which was not a common practice endorsed in the US. These rituals involved activities like grave sweeping, burning incense and paper money over an ancestor's grave, and making food offerings to ancestors. Historically, ritual has been essential to the fabric of Chinese society (Aijmer 1968; Kern 2007; Ward 1979; Sutton 2007; Teiser 1986), with particular emphasis on the rites of death (Baker 1965; Brook 1989; Sutton 2007; Teiser 1986). The fact that Chinese culture has been steeped in ritual practices illustrates how culture might shape expressions of spirituality.

Manifestations of metaphysical phenomena varied with culturally specific symbols and contexts, and this may in part be explained by research on culture's relationship to perception (Segall et al. 1968; Ji et al. 2000; Nisbett and Miyamoto 2005). Extrasensory perception was more commonly reported in the US (51\%) and China (56\%). Common types of extrasensory experiences reported in these two countries were realistic dreams ( $25 \%$ and $34 \%$, respectively) and intuitive impressions $(27 \%$ and $32 \%$, respectively). Telepathy, clairvoyance, and precognition were reported with relative moderate frequency across countries. Clairvoyance was more highly reported in the US. US participants more frequently mention extrasensory experiences involving survival hypothesis $(30 \%)$ (i.e., the notion that life continues after death). Specifically, this took the form of apparitional experiences (as opposed to near death or out of body experiences). Finally, faith or energy healing was more commonly reported in India $(29 \%)$, with stories often involving miracles and recovery from illness. 


\subsection{Cultural and Historical Factors}

In the US sample, descriptions of spiritual experience were often rooted in religious beliefs, specifically within Christian faith. Concurrently, participants often reported belief in religion and spirituality as two separate phenomena, with some responses highlighting agnosticism and belief in spirituality but not religion. There were also reports of religious beliefs outside of Christian faith (e.g., Buddhism, Judaism, Islam). Participants frequently reported feeling a sense of spiritual "oneness" through nature, prayer, and mind-body practice. Experiences with animals, both in the context of nature and domestic settings, were often accompanied by loss, increased empathy, and anthropomorphism. These findings suggest that spiritual attribution appears widespread in the US. In a national survey of the US, 76 percent agreed with the statement "I experience something more sacred in life than simply material existence" (Nickolas et al. 2009).

The US sample reported a relatively higher degree of spiritual exploration, as evidenced by reports of religious conversion. This included conversion out of a religion (primarily Christianity) and reports of converting to a new religion (e.g., Buddhism). The literature attributes the tendency for religious conversion in the US as a consequence of its materialist and individualistic society (Rambo 1999; Sherkat and Wilson 1995; Smith and Sikkink 2003). Sherkat and Wilson's (1995) paradigm of religious mobility describes religion in the US as a "marketplace of freely choosing individuals" (p. 993). The findings of our study support this idea, with US participants frequently describing conversion or changes in religious preference, which often resulted in a departure from faith traditions endorsed by family origins. At times, participants go as far as to report disillusionment and disdain towards religious institutions. This was in contrast to the participants in China and India, where religious life and spiritual practices tended to be more collectivistic and family centered.

The India sample was somewhat more eclectic in terms of faith, spiritual tradition, and lived experience of spirituality. Responses from these participants seemed to suggest that the transcendent world of spirituality is very much "real" to these participants, and many were leaning on faith and spirituality in meaningful ways throughout various aspects of their lives. Additionally, there were frequent reports of mental illness and conditions of adversity in this sample, which subsequently became a doorway to spiritual experience. Relatedly, this sample reported a great deal of faith healing or energy healing. The common pathways to spirituality included typical avenues such as prayer, visiting temples or churches, and consulting with spiritual and religious professionals; however, the widespread use of fasting as a religious practice was relatively unique to this sample. Furthermore, it seemed that these participants relied heavily on prayer, not only in religious traditions or places of worship, but also throughout daily life, and both when things were going well and when faced with adversity.

Participants from India provided much lengthier and richer responses compared to participants from the US and China. This may be an artifact of the moderately higher level of education in the India sample. Research has shown education level to predict survey participation (Sax et al. 2003; Malhotra 2008). More participants in the India (40\%) sample reported obtaining a graduate degree compared to the US $(13 \%)$ and China $(6 \%)$. The pattern of response from participants in the India sample may also reflect the legacy of colonialism. During British rule, religious practices and traditions were publicly discouraged and subject to criticism (Bellenoit 2007; Dirks 1997; Roy 2006; Thapar 1989). Those who engaged in extreme religious practices were cast by the British Media as victims, and the practices themselves were described as "revolting" (Dirks 1997, p. 219). Perhaps this may partially explain why participants from India tended to apologetically couch their narratives with statements such as "this may be too religious." Lastly, colonialism led to the proliferation of Christian missionary expeditions to India (Bellenoit 2007; Miller and Stanczak 2009; Roy 2006), which brought the language and symbolism of Christian faith into civil discourse. The high prevalence of Christian-based prayer may be rooted in this legacy.

In the China sample, there were frequent reports of stress related to university entrance exams. This important milestone task (Davey et al. 2007; Ross and Wang 2010; Yu and Suen 2005) was 
mentioned in many of the participants accounts of realistic dreams and intuitive impressions (e.g., an inkling, without rational logical thought processes, often accompanied with imagery, that was subsequently borne out). Other realistic dreams involved ancestors. Ancestor visitation was related to the phenomenon of "spirit possession," and a great deal of the faith/energy healing stories were associated with prayer or ritual. The most common profile of this phenomenon includes "possession" by an ancestor, where someone would then become physically ill. Subsequent ritual with spiritual or religious practitioners (e.g., monks, fortune tellers, and psychics), prayer directed towards traditional religious figures (e.g., Kwan Yin), and burning of symbolic items such as paper money over the ancestor's grave, were attributed to curing the participant of the persistent physical ailment. Oftentimes, the spiritual practitioners were relatives. Lastly, when animals were mentioned, they were perceived to be harbingers of death.

These findings regarding ancestor dreams and intuitive impressions suggest that, in China, access to the transcendent realm often begins with a journey inward. In fact, China can be said to have a "dream culture," and there exists an extensive literature on dream interpretation dating far back into China's ancient past (Li 1999; Ong 1985; Raphals 2014; Thompson 1988). This legacy suggests that the content of dreams has become a culturally accepted and relied upon source of information. Chinese participants appeared more attuned to the content of their dreams, often recalling dreams in vivid detail, processing their dreams with important others in order to connect with and honor ancestors, or attributing dream experiences to waking-life concerns, fortune, and future events. Perhaps placing awareness on this state of consciousness, between dreaming and waking, may explain how these dream-based seemingly supernatural experiences sustain themselves (Luhrmann 2014; Davidson 1976; Thaibourne and Delin 1999; Walsh 1989).

Despite describing many avenues to spirituality in personal and home life, a majority of the Chinese sample rated spirituality as not important at all or moderately important in their lives. Political forces in China may influence religious affiliation and attendance. In recent history, China has witnessed periods where religious freedoms were curtailed and religious practices were discouraged (Grim and Finke 2007; Potter 2003; Reinstein 2004). This history may have shaped the contemporary fabric of China's spiritual world and language. Despite having culturally-based ancestral practices and emphasis on the reality of dreams and intuition, very few participants in this sample commented on experiences with religious professionals (7\%), and nearly half of the sample described themselves as atheist. The latter was surprising given that "non-religious" and "other" were also available answer choices in the demographics portion of the questionnaire (see Table 1). These findings corroborate past research that has found a majority of the Chinese population to be non-religious (Cao 2012; Grim and Finke 2007; Hsieh 1986; Rottman et al. 2017).

\subsection{Theory of Religion and Culture}

A prominent thought in traditional theory is that religion and spirituality are fundamentally experiential. Theologian Friedrich Schleiermacher describes the true heart of religion as experience and feeling (Gerrish 2001; Niebuhr 1964). Rudolph Otto also writes of numinous encounters (i.e., involving the presence of something sacred or divine) as being central to religion (Otto [1917] 1958). William James, a Harvard University psychologist and philosopher, states in his book The Varieties of Religious Experience "if religion be a function by which either God's cause or man's cause is to be really advanced, then he who lives the life of it, however narrowly, is a better servant than he who merely knows about it, however much" (James [1902] 1977, p. 761). James suggests that mystical experiences drive all other outward vestiges of religion (Bixler 1926). The findings from our study support this idea, given that the experience of metaphysical phenomena was the greatest commonality among participants across countries. Although participants from China reported low importance of religion and spirituality, frequency of metaphysical phenomena was comparable to that reported in India and the US. 
Sociological interpretations of religion have suggested that religion and spirituality are fundamentally social phenomena. Prominent among these interpretations is that of French sociologist, Emile Durkheim, who believed that the underpinnings of both religious and spiritual life were the distinctions made between the sacred and profane (Alexander 1990; Paden 1991; Worsley 1956). He describes this distinction as a pathway to the adoption of symbols called totems (such as animals or forces of nature), which communities would worship and regard as sacred (McKinnon 2014; Rol 2012; Worsley 1956). Modern sociologists have also identified the enormous power of symbols in facilitating meaning-making, and described how symbols play an essential role in human communication, a process referred to as symbolic interactionism (Reynolds and Herman 1994). In all three countries, there were mentions of animals and nature, with particularly frequent reports from participants in China and the US. Social Interactionist Theory also places value in the context or circumstances around the adoption of symbols and their exchange among a culture (Blumer 1986). In India, reports of heirophany (religious figures) were more prevalent, and this may suggest that in India totems are linked to mythology from sacred texts (Kandari et al. 2014; Loh 2014; Prabhavananda 2019) rather than animals or forces of nature. In India, there exists a long history of worship towards regionally-specific deities (Hornell 1944; Kent 2013; Preston 2002).

Durkheim's sacred-profane dichotomy also suggests that through social designation of certain things as sacred, ordinary, or profane, the collective symbols and totems of a society give rise to religion. Rituals and other religious practices are a means through which to overcome this dichotomy, which transforms spiritual life into a process or activity. In contemporary sociological perspectives of religion, this is often referred to as lived religion (i.e., spiritual practice and experience in daily life; Edgell 2012). Hall (1997) illustrates this idea, stating "workplaces, homes, and streets-as well as churches, temples, shrines, class meetings ... are the places where humans make something out of the worlds they have found themselves thrown into, and, in turn, it is through these subtle, intimate, quotidian actions on the world that meanings are made, known, and verified" (p. 7). In China, spirituality takes on this quality by mention of ancestors, realistic dreams, and intuitive impressions, all of which are pathways to spirituality that are accessible in everyday life, routine, and close community. While India, like the US, had more mentions of engaging in religious traditions than China (see Table 2), rituals and spiritual importance tended to be infused into daily life in India.

Lived religion was not as prominent in US spiritual narratives, and nearly half of the US sample rated spirituality as not important at all while the remainder of the sample rated it as only slightly or moderately important. Perhaps this lack of endorsement of spirituality in the US reflects the impact of cultural movements which have splintered the religious scene into a dialectic. Roof and McKinney (1987) point to the counterculture of the 1960s and a rise in evangelical activities in the 1970s as two forces which are responsible for a "religious scene in flux" (p. 3) in the United States. The US participants also more highly endorsed religious conversion relative to China and India (see Table 2), which may reflect the materialistic culture of America. In his book Spiritual Marketplace, Roof (2001) states, "moral and religious coherence remains more an ideal than a practical reality" (p. 294). In contrast to a "spiritual marketplace," in China, only state-run religions are tolerated while non-state religious observance is persecuted (Beckford and Richardson 2007). This has led to criticism of religious practices (Cao 2012; Grim and Finke 2007; Hsieh 1986; Rottman et al. 2017; Reinstein 2004). This may explain why close to $80 \%$ of the China sample reported spirituality as being not important at all or moderately important. Beckford and Richardson (2007) assert, " ... religion is subject to self-regulation as well as to regulation by external agencies. It is also resistant to some attempts to regulate it; and, in turn, it seeks to regulate aspects of social life in accordance with its own values" (p. 414). This aligns with the narratives of Chinese participants who did not endorse spirituality as important, yet provided multiple examples of "lived religion."

Finally, anthropological theories have suggested that the driving force behind religion and spirituality is culture. Anthropologist Clifford Geertz (1993) offers a theory of religion which describes religion as a language or map providing guidance on both what is (reality) and how to act (morality). 
Geertz believed that members come to adopt religion as true through five pathways: tradition, personal experience, charismatic leaders, readings of holy text, and ritual (Geertz 1993; Segal 2012). Overall, in this sample, personal experience seemed to be the primary pathway through which participants encounter religion and spirituality. In the US and India, religious traditions were also viable pathways. Prevalent reports of religious figures by the India sample suggests that charismatic leaders may be a particularly common route to religious and spiritual life in this country. Reading of holy texts was most likely to occur in the US and China, suggesting that reading is another pathway. One participant from China stated "when I read Buddhist Classics, I almost burst into tears." Lastly, mentions of ritual were moderately reported in all three countries, most often taking the form of making offerings or burning incense. The exception being China, where rituals around ancestral worship were relatively more frequently reported. For the China sample, ancestrally-based ritual may be one of the primary pathways through which religious and spiritual life is accessed.

\section{Limitations}

Several limitations of the current study are largely related to the online method of data collection, which is susceptible to having participants rush through tasks, fail to pay attention, or take the survey multiple times with different usernames (Johnson and Borden 2012). In this study, the online method of data collection gave rise to various demographic differences. The India sample was of a relatively higher socio-economic status than the China and US samples. The China sample was slightly younger in age than the India and US sample. Another limitation in the methodology was the indication in the survey itself that the researchers were from a Western institution, which could have shaped participants' responses. Additionally, one of the qualitative questions prompted for common spiritual events, which risked over-representation of these themes in the data. The self-report questionnaire may have influenced the sort of information that was captured, and crucial information may have been lost or re-shaped to fit the nature of the prompts. The India survey was delivered in English rather than Hindi, and it is unclear whether the pattern of responses may have been impacted by this choice. Lastly, the online nature of this study could not capture the spiritual life of indigenous groups which populate all three countries.

Another consideration of this study centers around participants' access and awareness of religious and spiritual traditions. Religious and spiritual engagement and discussion may become increasingly marginalized as the secular-materialist perspective becomes more prominent with globalization (Ager and Ager 2011). Given that this study was delivered online, the anonymity of this process may have encouraged participants to be open about their beliefs and experiences. Nevertheless, the impact of the secular-materialist worldview may also have discouraged participants from being completely forthcoming. This is supported by the fact that participants in the US wrote relatively shorter responses to the qualitative questions, while participants in India, where culture and spirituality are relatively more readily intertwined, provided responses which were relatively more comprehensive.

\section{Future Directions}

The findings of the current study provide a conceptual framework for a body of emerging research around universal spirituality. The qualitative narratives also provide rich examples of the ways in which culture shapes the expression of spiritual life. Further research is certainly needed to clarify nuanced thematic and meaning-based categories of spiritual life, using methods and assessments that contextualize findings from a culturally humble lens. In particular, there is a need for quantitative approaches to capture broad dimensions of spiritual life in samples that allow for generalization to populations, as well as qualitative and mixed-methods approaches to help bypass scale-related biases and limitations (e.g., using predominantly Western tools in non-Western cultural contexts). The results of this study provide a rationale for developing better measures to assess the underpinnings of spiritual life, a phenomenon which may have cross-culturally innate components and processes, along with qualitatively unique and divergent manifestations. Additionally, future research might 
employ thematic analysis to deepen interpretations of the transformative aspects of spiritual and peak experiences. Finally, additional exploration into spirituality and its cultural expressions must begin to account for the spiritual lives and narratives of less industrialized and rural communities, which likely hold unique traditions, voices, and legacies.

Author Contributions: Conceptualization: E.L. and L.M. Formal analysis: E.L., M.G., A.N. and A.G. Funding acquisition: L.M. Investigation: E.L. Methodology: E.L. Project administration: E.L. and C.M. Resources: L.M. Writing—original draft: E.L., M.G., A.N. and A.G. Writing-review \& editing: E.L., M.G. and L.M. All authors have read and agreed to the published version of the manuscript.

Funding: Board of Trustees, Teachers College.

Conflicts of Interest: The authors declare no conflict of interest.

\section{Appendix A. Exemplar Excerpts of the Coding Frame}

Appendix A.1. Religion

Religious Tradition

"Once when I read Buddhist Classics, I almost burst into tears. Another time I joined a three-day Buddhist ceremony (walking around the Buddha's statue day and night) by Master Jing Kong. I felt relaxed, my body and soul relieved as if I put down some heavy burden. I could also sense my inner kindness, which was completely different from the bad tempered person that I used to be." (China)

"I have had many significant spiritual experiences, it's impossible to say which is the most so, but the earliest one I can recall plainly happened when I was 12, that summer. My parents were fighting constantly (father was an abusive cheat, Mom grew a spy that year), I felt alone, frightened, unwanted, and homesick as hell. Years earlier, I'd heard someone give a sermon on the concept of God as "Abba", the Hebrew for "da-da", and the idea of God as the Daddy I ached for was hugely compelling. I prayed to "Abba" or "Daddy" ever after. On this particular day, I was hiding in the woods to get out of the house, they were fighting again and I didn't want to listen. I was sitting on the swing behind our house, just swinging as hard as I could, crying, and sayin "Daddy I want to come home, I don't like it here" over and over. I do not to this day remember making a conscious decision to jump. What I remember is passing the point of no return, the last moment when I could have grabbed the rope and stopped myself from falling, and choosing not to grab hold. This swing went out over a very sharp drop-off, high enough to call a cliff, really. At the apex of the swing's motion, a rider is a good forty feet in the air. I just pitched forward off the swing, and the way I fell, I SHOULD have landed head-first and died right there. The instant I passed that point of no return and began to fall in earnest, I felt extremely large hands on me, on my back and on my right shoulder. These hands pushed me, turned me in the air, and when I hit the ground, it was on my right shoulder, and with enough spin that I rolled rather than impacting with any damaging force. The lower part of that drop-off is covered with rocks and briars, but I didn't get a single scratch, despite being dressed in shorts and a tank top. When I stopped tumbling, I just sat at the bottom of the ravine for a while, processing. Looking around, realizing how tall someone would have to have been to touch me up there. Ever since that day, I've known without question that there is a reason for me being here, and I'll get home when it's time to go, not before. It doesn't make life any better or worse really, it's just a reality, but ... it is oddly comforting and obnoxious by turns to know that there's a reason, even if I can't get my head around what that reason could be. I believe that my aborted suicide attempt was stopped by an angel, though I didn't see it there. The hands I felt were inhumanly large, even against the measure of a 12 year old's body, and no human has the reach to turn me midair as was done. There have been many times I have sensed the presence of divine beings, heard voices, felt hands that weren't there, far too many to describe here or choose between. Being open to these experiences gives me hope, conviction that there is more beyond this life." (USA) 


\section{Appendix A.2. Religious Conversion}

\section{Appendix A.2.1. Convert Back into a Religion}

"My spiritual life story is long and varied. Being a child of a part-time preacher, I learned a lot about religious rituals and beliefs from an early age. But by high school, I began to feel that religion was routine and distant. In college, I was briefly an atheist. Thinking that God may or may not be real, I then became agnostic, not really sure of who or what God was supposed to be. A couple of years later, I met a co-worker who answered my questions about God, Christianity, and the Bible. I admired this person because he was so confident and genuine about his faith. I wanted that too, so one night after work, I prayed with him and a friend, and became a born-again Christian." (USA)

\section{Appendix A.2.2. Convert into a Religion}

"My most significant spiritual experience was deciding to trust in Jesus as the Christ. Sorry if that comes across as "too church" or "too religion" or too (anything else). But it was significant in that it was the starting point of too many other significant spiritual experiences/encounters to count. It was the "getting first things first" — the foundation upon which all other experiences and adventures built. Before that it was as if "life was living me." Now I'm the one living life." (India)

\section{Appendix A.2.3. Convert Out of a Religion}

"My friend Rani story: as she was making morning rounds, the palliative care nurse noticed that Mrs. Rani held something shiny in her left hand. The nurse easily identified the object as a rosary but was confused because Mrs. Rani had clearly stated on her admission form that she had "no religious affiliation." Later that day when Mrs. Rani's niece was visiting, the nurse asked if the rosary held special meaning for the patient. The niece burst into tears, confessing that the patient had left the Catholic Church many years ago and had never wanted to rejoin, even as she was dying. Upon further exploration, the niece confessed she was worried that if her aunt died outside of the church, they would never meet again in heaven. After expressing sympathy for her concern, the nurse asked the niece if it would be helpful for her to speak with the hospital's Cathedral chaplain." (India)

\section{Appendix A.2.4. Religious Professionals}

"Guru (Master) is the most significant figure. Guru (Master) guides me to spiritual path, solves problems during meditation, shows ways to overcome shortcomings. He is the leading Light on the path of spiritual and religious growth. It said that The God and he Guru (Master) both are in front of me that to whom I will pray first God or Guru. He is Guru who has shown me the path towards God. Due to his guidance I have reached to this height. So first I will pray to my Guru and thereafter the God." (India)

"I have become close to my spouse's mother, who is a minister aligned with fundamentalist Christianity. For a long time I viewed this particular belief system to be deeply flawed in terms of both its tenets and their application to people in their everyday lives, and I still harbor many reservations about it as often practiced in the US. However, as I have gotten to know my mother-in-law and have had conversations with her about her beliefs and spiritual journey within that framework, I have found myself reflecting on her experiences as a mirror at times of my own questioning of my own progress in striving to be closer to God. She has helped focus my attention in new ways on matters of a spiritual nature and helped me progress on my own path, even though it is very different in nature from hers." (USA)

\section{Appendix A.3. Religious Figure (Theophany)}

"During mom's cancer therapy, I met an angel with wings in my dream who comforted me and said that everything will be ok." (China) 
"The Goddess of Mercy. When I was little and saw the Goddess of Mercy in Journey to the West [movie], I felt her divinity. I didn't understand the world at that time. Whenever I encountered difficulties, I prayed to the Goddess of Mercy, and then things developed to the direction of what I prayed for. Eventually, the Goddess of Mercy becomes one of the most important figures for my spiritual growth." (China)

"The place which I was is very famous for Lord Krishna and situated in Uttar Pradesh. I even today understand that Lord Krishna has helped me via some unknown person." (India)

"I have had many significant spiritual experiences, it's impossible to say which is the most so, but the earliest one I can recall plainly happened when I was 12, that summer. My parents were fighting constantly (father was an abusive cheat, Mom grew a spy that year), I felt alone, frightened, unwanted, and homesick as hell. Years earlier, I'd heard someone give a sermon on the concept of God as "Abba", the Hebrew for "da-da", and the idea of God as the Daddy I ached for was hugely compelling. I prayed to "Abba" or "Daddy" ever after. On this particular day, I was hiding in the woods to get out of the house, they were fighting again and I didn't want to listen. I was sitting on the swing behind our house, just swinging as hard as I could, crying, and sayin "Daddy I want to come home, I don't like it here" over and over. I do not to this day remember making a conscious decision to jump. What I remember is passing the point of no return, the last moment when I could have grabbed the rope and stopped myself from falling, and choosing not to grab hold. This swing went out over a very sharp drop-off, high enough to call a cliff, really. At the apex of the swing's motion, a rider is a good forty feet in the air. I just pitched forward off the swing, and the way I fell, I SHOULD have landed head-first and died right there. The instant I passed that point of no return and began to fall in earnest, I felt extremely large hands on me, on my back and on my right shoulder. These hands pushed me, turned me in the air, and when I hit the ground, it was on my right shoulder, and with enough spin that I rolled rather than impacting with any damaging force. The lower part of that drop-off is covered with rocks and briars, but I didn't get a single scratch, despite being dressed in shorts and a tank top. When I stopped tumbling, I just sat at the bottom of the ravine for a while, processing. Looking around, realizing how tall someone would have to have been to touch me up there. Ever since that day, I've known without question that there is a reason for me being here, and I'll get home when it's time to go, not before. It doesn't make life any better or worse really, it's just a reality, but ... it is oddly comforting and obnoxious by turns to know that there's a reason, even if I can't get my head around what that reason could be. I believe that my aborted suicide attempt was stopped by an angel, though I didn't see it there. The hands I felt were inhumanly large, even against the measure of a 12 year old's body, and no human has the reach to turn me midair as was done. There have been many times I have sensed the presence of divine beings, heard voices, felt hands that weren't there, far too many to describe here or choose between. Being open to these experiences gives me hope, conviction that there is more beyond this life." (USA)

\section{Appendix A.4. Religious Force (Hierophany)}

"From that time onward, I had a feeling that whatever happens is rather controlled by some other unknown factors than my ability. Then I started to look at every happening in my life from that angle and I was astonished to find that if it is intended by that superior force, it will be granted or in other words, has to happen by all means." (India)

"Felt the Holy Spirit. So intense and strong it is absolutely, positively, like no other feeling, it is pure Love from Father God and there is no doubt about it! I was raised Catholic and I have to say that I felt the presence of the Holy spirit in the Catholic Church especially when I was young boy however usually only when I prayed in Church and tears would come from my eyes, not of sorrow and not of my control, but tears of joy from being in the presence of the lord and feeling his Love. The Nuns at the Catholic school I went to would scold me and slap me on the wrists with their rulers. They thought I was crying and I tried explaining to them that I was not crying, I thought they were so cruel for doing this to me. I began to resent them and questioned whether they felt the love of God and if they did, 
What would cause them to treat me like that? I had a difficult time trying to understand why the Nuns "Godly Woman" would even think of doing that." (India)

Appendix A.5. Contemplative Practice

\section{Ritual}

“The neighbor grandpa always go to burn the first incense (烧头香) every year. People really believe it. Grandpa often told me some spiritual stories that he had experienced during childhood. Whether it was true or not, I felt it was wonderful because it increased my sense of spirituality. The grandpa also gave me prayer beads. I felt such cross-generation friendship is marvelous." (China)

\section{Meditation}

"About five years back, my aunt was diagnosed with breast cancer. Doctors had lost hope for her treatment. I was very stressed out during that period. I used to get irritated on the smallest of issues. During this time, a friend of mine suggested meditation. I started meditating for long hours daily on a regular basis. Meditation helped me calm my nerves. I started facing adversity in the eye with a smile on my face. My aunt passed away after one year; however, I had made myself mentally strong enough to cope through the loss." (India)

\section{Mind-Body Practices}

"I had done the Art of living course conducted by Sri Ravishankar. This involved certain breathing techniques combined with meditation. I was at that time so much desperate in life that this course was a rejuvenating experience to me. While doing the Sudarshan Kriya one of the techniques in this course, I felt that my entire body had become numb and that I am just a floating energy. At that time I felt the divine presence of God too. I was so much deeply immersed in the feeling that tears broke out from my eyes." (India)

\section{Prayer}

"Maybe my lasting health is due to my mother praying to and worshipping the gods." (China)

"Last year when my grandmother passed away, I prayed for her. This deeply relieved my sorrow." (China)

\section{Appendix A.6. Ancestors}

\section{Ancestor Mentioned}

"My great grandpa passed away. That night he said he was thirsty and wanted to eat some litchi and dad went out to buy litchi. When he came back, great grandpa had passed away. According to the doctor, he passed away without any illness. He was considered as having done many good deeds in his life so that he could have such a perfect ending." (China)

\section{Ancestral Worship}

"I never personally experienced this, but my grandma or mother has. Sometimes they would dream of deceased family members telling them that they don't have enough money or their home is broken. The next day, my family would visit the ancestor's grave and burn incense and paper money for them." (China)

"After grandma passed away, food was placed on the altar to give sacrifice to her. That night, I dreamt of grandma enjoying the food. Before she passed away, she was hungry because she could not eat much." (China) 


\section{Dreams about Ancestors}

"My mom had such a dream. She dreamed of an ancestor telling her that her house was broken by a falling tree. Then we went to the grave of our ancestors, and there was really a tree on it. We moved the tree away afterwards." (China)

"Early in the morning when grandpa passed away, I dreamt of his wheeze, the sound which was the result of his bronchitis. I did not know he passed away until next day. I felt that he wanted to say goodbye to me." (China)

"A few nights ago I had a dream and in my dream my Nana Heath was in it, she passed 12 years ago. All I remember from the dream was that we were at my house at some kind of family gathering (probably a birthday party) and I remember looking over and she was there. We didn't talk or anything she was just kind of there and it felt so real and it's like in my dream she was still alive cause it didn't cross my mind that she had passed it's as if in my dream she never did, that's how real it seemed. But we didn't talk or anything she just sat there I looked at her and she looked at me." (India)

"The night my grandmother died I dreamed of her. She was surrounded by land and trees and birds and squirrels and cats. She loved her small furry creatures. And she was happy and singing. The next day my mother told me that she received a call from Joran and that tayta was gone." (USA)

\section{Appendix A.7. Natural World}

\section{Animals}

"I was a graduate student doing my thesis research on the effects of disturbance on raptors (birds of prey) and spent each day alone in a beautiful natural area watching and interacting with wildlife. During a meeting with my major professor, he mentioned that his previous graduate student was a "flake" and she had all sorts of mystical, spiritual beliefs about the hawks she was supposed to be studying. At that time, I agreed that anthropomorphism had no place in ecological research and didn't give much thought to his comments. During the next summer, however, I began to recognize individual raptors from the previous year, as well as their progeny. I began to feel invested in their success. One day I was hiking along a creek bed looking for nests and saw a huge stick nest that could have only been made by one large bird: golden eagle! As I crept near the base of the nest tree, I found a blood pool and then saw the carnage. One large adult golden eagle was dead on the ground and her feet had been removed, most of her tail feathers pulled out, and she had bullet holes in her breast. Clearly, she had been killed for the illegal trade in "parts". It made me extremely sad and angry that such a beautiful creature had been slaughtered. I climbed into the nest and found two dead chicks, presumably they starved to death after their mother was shot (this disturbance likely led to the father abandoning the nest-in any case, it wouldn't matter since it takes two eagles to raise a brood). As I left the nest tree and began walking back the way I came, I found the male. He was under some brush, barely alive, and on the edge of starvation. All I could think about was saving him. I took off my shirt, balled it up, and let him grab it with his feet so that I could safely grab around his legs and around his wings. I hiked four miles back to my truck cradling him like a baby. I drove to the college of veterinary medicine and staff immediately took him into X-ray." (USA)

"Soon after the small service, while walking with my recently widowed mother, through the entire walk back to the car from the grave site, a beautiful butterfly darted back and forth, leading us for nearly a hundred yards, as we walked alone in grief together. We spoke later about it, "Did you see that?", yes, we both did, and we both felt a presence along with it, and a sense that everything would be OK." (USA)

"I suffered greatly when the two dogs who had shared more than ten years of my life with me both died within the space of a little more than a year. During our lives together we spent many days on wilderness trips experiencing the joy and fulfillment of oneness with nature. Recalling these feelings and experiences through the lens of their larger spiritual dimension helped me deal with the loss of my dogs and the void they left in my everyday existence. It underscored that they were still a 
part of me and alive within me even though their corporal existence had ended. There was comfort in that in a very dark time for me." (USA)

\section{Nature}

"Once went out to travel, went deep into the mountains and felt I am in one with the nature around me. My body is not only controlled by myself, but it acts with wind, with bird singing, with the sound of water." (China)

"It made me feel connected to nature on an entirely personal, not professional level. I felt a more profound respect and awe than I ever had as a scientist. I began to see the lives of other living creatures as being just as important and as rich as my own. I began to see just how selfish, arrogant, and entitled most humans from industrialized nations were and how this loss of respect and awe for nature has been ruining this planet. Trying to live lightly-being vegan, growing my own food, being as self-sufficient as possible, not being a mindless consumer-is my daily reality and gives my life a deep sense of purpose. I chose to live on a remote acreage in an otherwise row-cropped area. I have allowed natural succession to occur on my 5 acres and the diversity of life here is amazing. Despite being surrounded by GMO corn and soybeans, my land is a refuge for many threatened species found nowhere else in the state. I feel I am the keeper of this little sanctuary." (USA)

"I was raised within the Roman Catholic faith by parents who were not strict in their beliefs. I accepted that the church was a positive force in the world but doubted the existence of God and disagreed with the teachings of the church about some matters. The experience of living in a different culture in Asia for a year when I was in college broadened my horizons about spiritual matters. As I previously wrote, I had an enlightening experience at a religious festival that convinced me of God's existence. This occurred in tandem with a growing sense of spiritual identification with nature that I felt when I was pursuing activities like backpacking and mountaineering, a feeling of oneness and belonging and purpose in life. Over time I have reflected on these experiences and discoveries and integrated them into my sense of self and sense of spiritual identity, while gradually coming closer to integrating them within the religious tradition in which I was raised." (USA)

\section{Appendix A.8. Metaphysical Phenomena}

Appendix A.8.1. Extrasensory Experience (ESP)

Telepathy

"When I was a child, I accidentally injured my knee once. My mom felt intense pain in the same place in her knee at the same time. Soon she got the phone call from school to ask her to go to the hospital ASAP." (China)

"The thoughts of powers superior to humans did not happen to me from books. It all started when I started with computers. I was into software development and everything was new to me. After I completed a course in computer application development, I joined a firm mainly into software development. As it was a small firm, I got very good exposure in the entire software development life cycle. I used to analyze and develop systems in programming languages prominent those days. While programming, I had a peculiar feeling that I was getting ideas and problem solving skill which was not mine. While trying to design comparatively sophisticated areas of some systems, many options to carry out them were really popping in my mind when I think about a way for it. These were very unique and I never had any exposure or knowledge in those areas. It really was astonishing to me that these are not already coded in my brain and are popping out when I was trying to fetch them. Then this happens only if I am getting connected with an external force. So I started thinking that way. What if my thoughts are coming from outside. At times I sat without deliberately thinking about anything in particular. Then from nowhere thoughts were coming in and when concentrating on them, I found that most of them are not having any connection with what I know or what I am directly involved with. It's like a seed and it starts germinating and grow with what we have already coded or 
make us start working to develop them. The whole thought process seems to be a discussion between oneself and the external force." (India)

\section{Clairvoyance}

"In high school, my uncle who really loved me suddenly passed away. That night, I was in class. Suddenly, for no reason, my heart was pounding and hands shaking. I couldn't even speak. My desk mate held me in the arms for more than ten minutes before I could calm down. The next moment, my mother told me about my uncle's death. My uncle especially loved me dearly since I was young. The night he passed away gave me the greatest shock. I think it's because he cared about me the most, so we had such a strong telepathy when he passed away." (China)

"It happened when I was in high school. There was one morning after I woke up; I walked out from the dorm entrance and saw a bright red light before dawn. My heart pounded fiercely. This has never happened before. 9 o'clock that morning, my father came to school and told me that my grandfather passed away that morning. I think this was a sign from my religion. It informed me about my family member's death. I thought of it at that moment. It connected my grandfather and I." (China)

\section{Precognition}

"Oh also when I was 16 in the very early morning hours of 9/11/01, I couldn't sleep and I wrote my mom this note saying that I loved her, which wasn't characteristic of me. I probably wouldn't remember this today if we hadn't had a terrorist attack a few hours later." (USA)

"Sometimes I kept feeling something bad would happen and it did. Once I had a car accident but not serious. The night before the accident I felt I saw a lot of information about the car crash." (China)

\section{Realistic Dreams}

"Shortly after my husband and I were first married, we spent an evening doing the baby names thing. We got it down to two boys and two girls that we both liked before going to bed. That night, we both had the same dream, seeing all four children, in extensive detail. The next morning we were both acting a bit strange. Someone (I don't recall which of us) asked if the other had a weird dream, and the other started to describe. I said "Stop. Go write it down." or words to that effect. When we compared notes, it quickly became clear that we had seen the same four children. I have known since 2006 that I have four children, their names, their birth order, their looks, the sound of their laughter, who is quiet and thoughtful and who is impulsive and passionate. The first two of those children are here, in order, looking exactly the way our written accounts described (we kept them, you see). Our first son is three years old, and our first daughter is four months, and has the birthmark we saw." (USA)

"Around age 10, I often dreamt about a scene that I tripped over on a very high bridge and fell in a river directly. There was a period of time when this dream happened frequently. Sometimes, this scene popped up when I was falling asleep. It turned out that one day, my bicycle wheel got stuck in the crevasse on the bridge. Then my bike and I fell into the river, just as it was in the dream. Fortunately, the water brought me back to the land. I was not hurt. After this incident, I have never dreamt about that scene again." (China)

"I was staying in a rented house while being posted in another state during my job. One day my landlord came to me and told me that he has to get his daughter married so I will have to vacate his house till the marriage. That night I was thinking of how early would I get a new house and weird thoughts went through my mind. Then in my dream I saw my grandmother come to me and tell me I will not be able to change my house. I was arguing with her that my landlord has already given me the ultimatum to move out. My grandmother still insisted I will not be able to change my house. Thinking of this weird dream I started my daily chore and went to office. Later that evening my landlord came to me and told me he has made alternate arrangements for his guests and that I need not move out of his house during the marriage. I could not believe my ears nor could I believe that I was told about it by my grandmother in the night." (India) 


\section{Intuitive Impressions and Synchronicity}

"My car had broken down, overheated. For some unknown reason, I had a jug of water in the back, which I never normally kept. I poured the water into the radiator, and it got me just far enough as it began to overheat again, to coast with the engine off into a parking lot. That lot happened to be an auto parts store. In addition, by the door of the store stood a man with a tool bag on the ground by his side. As it turned out, he was a mechanic, who had just gotten off duty. Also, as it turned out, he specialized in my make of car. Also, as it turned out, he troubleshot the problem and the store happened to have the hose he needed to repair my car. Also, as it turned out, the kind parts store owner did not charge me for the part. Also, as it turned out, I had 40 dollars cash on me, which I rarely carry, but was more than happy to pay that off-duty mechanic after he repaired my car and I was on my way." (USA)

"A few times, strangely I have a very clear feeling of familiarity of having been to some place before I even went there for the first time." (China)

\section{Appendix A.8.2. Psychokinesis}

"I used to dream about my grandmother who has passed away for many years. The interesting things is she does not know how to ride a bike, but in the dream, she was chasing me while riding a bike. The whole time she was trying to give me a blanket and said "this blanket is new. Take it and use it!" When I woke up the next morning, I found myself covered with a blanket which was previously stored in the corner of my room. The weather that night became freezingly cold all of a sudden. I was very touched at that time." (China)

"I felt that I could control the wind, when I opened my hands, it became bigger; when I closed my hands, it became smaller." (China)

"I have felt that sense many times in prayer especially healing masses when the priest places his hands on you and you can feel the holy Spirit so strongly that it knocks you right off your feet. You can't stop yourself from falling no matter how hard you try and I have tried. I did not want to be one of those people that fell backward and had to be caught." (USA)

\section{Appendix A.8.3. Survival Hypothesis}

Near Death Experience

“Once I went travelling, I fainted during the trip. Unconsciously, I seemed to arrive at the gate of an unfamiliar building. The surrounding was hard to see because of the fog. Later I thought it may be what the soul sees in near-death stage." (China)

"It was a morning in the month of Sept 1996. The place was Peermade of Kerala state in India. Suddenly my eyes became closed, I fell into a trance and gradually lost my body sense. It seemed to me that my soul coming out my body was approaching towards infinite galaxy. Everything including earth, stars etc. were out of my mind and reached a void zone. All on a sudden I got back my sense but could not fathom what it was. After long 10 years passing through innumerable realizations, I realized that I had a mariamman [goddess] at that time. In such a state the seer stands at the junction of death and life. Anybody at this state generally crosses the door of life and enters death world. But if he has the blessings of God, he returns which happens in my case. Later on I came to know that this was the initiation of my divine life which flourished by the achievement of God-the-Preceptor who always guided and taught me throughout my life in the spiritual world." (India)

\section{Out of Body Experience}

"One day I woke up, and I realized everything has changed. As I looked around, I felt like I was looking through someone else's eyes. Everything looked as if I've never seen it before. Later that day, I began walking. As I passed people, I suddenly felt an emotional and spiritual connection, unlike anything I've ever felt before. I felt as if I wasn't controlling my body. As if I was just simply 
a spectator to my own life, or watching my life through another person's eyes. It was like a natural high or a euphoria. As I passed people, I could feel their emotions, and understand them as a person. I have become more aware of my feelings, thoughts, actions, speech, and impact. I don't know how else to explain it. It's almost frightening to an extent. I feel more connected to myself and to others. My thinking has also changed dramatically. I realized how clustered my mind is, and I can now break down my thoughts into a single thought. I don't know what it means. It feels like a superpower at times. I now feel like I have a better connection to this world, as if everything has beauty." (India)

\section{Apparitional Experience}

"I'm not sure if this counts, but after I came home from my grandmother's funeral, I sat on my bed. I don't recall ever falling asleep because I don't remember ever waking up. But I was sitting in my room and had a conversation with my grandmother. When it was over, I guess I woke up, but I wasn't really asleep. It's hard to describe. It was as if she took a moment to say bye." (USA)

"When I was 27, I was awakened one night by something that was so overwhelming I will never forget it. I woke up in the middle of the night and seen what I thought was Mother Mary "Almost Ghost like" hovering over the foot of my bed. I was so shocked I didn't know what to do. I closed my eyes and said the Lord's prayer and just as I did that she was gone. I was so amazed and somewhat scared I had to call my parents' house and let them know what had just happened." (India)

"I was only 5 years old at that time. I woke up at midnight and found that the window was gone. Instead, there was Buddha, with a metallic copper texture, sitting cross-legged, filling the whole window area. The image is not that different than the ones in temples. I am very certain that I was not dreaming at that time. It was real. I was not scared at all, at that time. This might be because I did not have any impression of Buddha when I was young. I looked at it for a while, and went back to sleep. I told my mom the next day about what I saw. My mom was very angry at that time, and said I learnt to lie at such a young age. No matter what I said, she wouldn't believe it!" (China)

"Kailee was a friend when I was little, like age 3-7. My mother knows the name as my "imaginary friend". My mother thinks "Kailee" and "tree-friend" were different imaginary friends, but they were the same person, I just couldn't wrap my mouth around her name at first. You see, I remember Kailee as clearly as I remember my parents, my brother, my favorite babysitter, more clearly than teachers, playmates, etc. There is no question in my mind that she was real, but no one else ever saw her. She lived in the woods behind my house, in a little clearing with a beautiful tree in the middle with small yellow flowers. (A linden tree, I drew the flowers and looked it up a few years ago.) Thus, "tree friend" before I could get my mouth to do "Kailee". Nothing about her seemed strange at the time, she was just my tall, happy friend who played with me and danced with me and sang me beautiful songs and taught me how to make flower crowns. But looking back with an adult's frame of reference, many things were out of the ordinary. She was ... stunningly beautiful. Black hair, emerald green eyes, Irish-redhead skin, tall and slim but curved and full-figured. I've drawn her and shown her to people who knew me then, and she doesn't look like anyone they've ever seen. "That's a face I'd remember" is the usual reaction. The clearing where she lived was always early summer, when it's gotten warm at night but the days aren't hot yet, and the tree was always in bloom, even if I found the glade in the middle of the winter. I know because a few times I got lost back there in the snow, and stopped in Kailee's clearing to get warm, and after that she would always walk me home, even carried me if the snow was too deep." (USA)

Appendix A.8.4. Faith/Energy Healing

Recovery from Illness

"One of my family members was sick and we went to a temple to burn incense and worship Buddha. From belief in Buddhism, he/she finally recovered and returned to the temple to show gratitude. Such kinds of tradition have been passed down in our region." (China) 
"Decades ago I broke my tailbone in the birth of our second child, our son. It took so long to heal and I was in considerable pain any time I had to sit. One Sunday in church, after 15 months of pain, I prayed and shared that I didn't think I could come to the service anymore due to the pain. I then returned to worship. At the end of the service I recognized that my tailbone didn't ache. And it never has again since then. That was 30 years ago." (USA)

"A professor, Sheikh and spiritual director in the Sufi tradition, shared with me his life-changing encounter with an angel. A couple of years ago he was in the hospital, at death's door due to a serious lung infection, feeling as if he were drowning. Finally he dozed, and saw an enormous Archangel place his hands on the left side of his chest and pull out "something." The Archangel communicated without words that all would be well, and that this was his initiation so that he could help others through the passageway to the Divine Light." (India)

"When I was very little, I was sick once, had a fever for a few days which wouldn't go away. In the end my mom brought me to attend Christian services. A lot of people stood in a circle around me. They sang and prayed and ended with "amen". Afterwards, I wasn't sure why my mind was clear, and soon I recovered. Since then I have some feelings toward Jesus which led to my faith today." (China)

"My relative (cousin) just nearly 28 years of old, unfortunately he suffered with Cancer, by God grace, he recovered and got cure after a healing through prayer of all our family members and friends, and after one year treatment and also with lot of Yagam, hmam and religious prayer, he got well. Now he has celebrated his 43rd birthday and also travel through the world for his business." (India)

\section{Spiritual Practitioners}

"When I was a child, I was sick and couldn't be cured in the hospital. Found the wizard in the village to use spells to exorcise sickness (sickness demon) and soon I was cured. Since then I started to believe in this sacred spiritual power." (China)

"My wife was suffering from a chronic stomach ache from years before marriage and was not able to be successful in her life because of that. She consulted many doctors and none was helpful. Everybody stated that it was all her feeling. But due to sudden vomiting temptations, frequent urination urges, intermittent, but severe stomach aches, she was very depressed of her situation at the time of her marriage with me. I consoled her and after marriage, we again visited many doctors, and once, she was directed to a psychologist. He told me to start some sedative treatments, but I was not willing to. At that time, from one of our acquaintances, we came to know about a saint living in a district called Alleppey in Kerala and we met him. He was a big devotee and through his guidance, we practiced more religious activities and engaged ourselves in spiritual way of life. This gradually brought happiness to our life and in the due course, the saint helped us by removing all our evils and negative energies from our bodies, and our life began to be meaningful. All this happened by the proper guidance by the saint, who didn't collect a single penny from us for his guidance. This led to me and my wife's spiritual beliefs to become stronger and started living a life in tune with God's principles of a healthy good lifestyle." (India)

"I am a reiki practitioner myself. We do healing by using universal power to flow through the chakras. People do healing in different ways." (India)

\section{References}

Ager, Alastair, and Joey Ager. 2011. Faith and the discourse of secular humanitarianism. Journal of Refugee Studie 24: 456-72. [CrossRef]

Aijmer, Göran. 1968. A structural approach to Chinese ancestor worship. Bijdragen tot de Taal- Land-en Volkenkunde 124: 91-98. [CrossRef]

Alexander, Jeffrey C. 1990. Durkheimian Sociology: Cultural Studies. Cambridge: Cambridge University Press. Angelskår, Trine. 2013. China's Buddhist Diplomacy. Available online: http://noref.no/Regions/Asia/Publications/ China-s-Buddhist-diplomacy/(language)/eng-US (accessed on 7 June 2020). 
Aurobindo, Sri. 1919. Indian Spirituality and Life-1. Available online: http://intyoga.online.fr/isl01.htm (accessed on 7 June 2020).

Baird, Robert D. 2004. Syncretism and the History of Religions. Edited by Syncretism A. Reader. London: Leopold \&Jensen, Equinox, pp. 48-58.

Baker, Hugh. 1965. Burial, geomancy and ancestor worship. In Aspects of Social Organization in the New Territories. Edited by Marjorie Topley. Hong Kong: Royal Asiatic Society, pp. 36-39.

Beckford, James A., and James T. Richardson. 2007. Religion and regulation. In The SAGE Handbook of the Sociology of Religion. Edited by James A. Beckford and N. J. Demerath III. London: SAGE Publications Ltd.

Bellenoit, Hayden J. A. 2007. Missionary education, religion and knowledge in India, c. 1880-1915. Modern Asian Studies 41: 369-94. [CrossRef]

Bengtson, Vern L., Merril Silverstein, Norella M. Putney, and Susan C. Harris. 2015. Does religiousness increase with age? Age changes and generational differences over 35 years. Journal for the Scientific Study of Religion 54: 363-79. [CrossRef]

Bhawuk, Dharm P. S. 2003. Culture's influence on creativity: The case of Indian spirituality. International Journal of Intercultural Relations 27: 1-22. [CrossRef]

Bixler, Julius Seelye. 1926. Religion in the Philosophy of William James. Boston: Marshall Jones.

Blumer, H. 1986. Symbolic Interactionism: Perspective and Method. Englewood Cliffs: Prentice-Hall-Inc.

Braun, Virginia, and Victoria Clarke. 2006. Using thematic analysis in psychology. Qualitative Research in Psychology 3: 77-101. [CrossRef]

Brook, Timothy. 1989. Funerary ritual and the building of lineages in late imperial china. Harvard Journal of Asiatic Studies 49: 465-99. [CrossRef]

Cao, Shixiong. 2012. Socioeconomic value of religion and the impacts of ideological change in China. Economic Modelling 29: 2621-26. [CrossRef]

Charmaz, Kathy. 2011. Grounded theory methods in social justice research. The Sage handbook of qualitative research 4: 359-80.

Chiu, Lyren, Julia D. Emblen, Lynn Van Hofwegen, Rick Sawatzky, and Heather Meyerhoff. 2004. An integrative review of the concept of spirituality in the health sciences. Western Journal of Nursing Research 26: 405-28. [CrossRef]

Dalal, Ajit K., and Girishwar Misra. 2010. The core and context of Indian psychology. Psychology E Developing Societies 22: 121-55.

Davey, Gareth, Chuan De Lian, and Louise Higgins. 2007. The university entrance examination system in China. Journal of Further and Higher Education 31: 385-96. [CrossRef]

Davidson, Julian M. 1976. The physiology of meditation and mystical states of consciousness. Perspectives in Biology and Medicine 19: 345-80. [CrossRef]

de Jager Meezenbroek, Eltica, Bert Garssen, Machteld van den Berg, Dirk Van Dierendonck, Adriaan Visser, and Wilmar B. Schaufeli. 2012. Measuring spirituality as a universal human experience: A review of spirituality questionnaires. Journal of Religion and Health 51: 336-54. [CrossRef] [PubMed]

Delaney, Colleen. 2005. The spirituality scale development and psychometric testing of a holistic instrument to assess the human spiritual dimension. Journal of Holistic Nursing 23: 145-67. [CrossRef] [PubMed]

Dirks, Nicholas B. 1997. The policing of tradition: Colonialism and anthropology in southern India. Comparative Studies in Society and History 39: 182-212.

Edgell, Penny. 2012. A cultural sociology of religion: New directions. Annual Review of Sociology 38: 247-65. [CrossRef]

Edwards, Adrian, Nannan Pang, Vanessa Shiu, and Cecilia Chan. 2010. The understanding of spirituality and the potential role of spiritual care in end-of-life and palliative care: A meta-study of qualitative research. Palliative Medicine 24: 753-770. [CrossRef]

Gaur, Kusum Lata, and Mahesh Sharma. 2014. Measuring Spiritual Health: Spiritual Health Assessment Scale (SHAS). International Journal of Innovative Research and Development 3: 63-67.

Geertz, Clifford. 1993. Religion as a cultural system. In The Interpretations of Cultures: Selected Essays. St Waukegan: Fontana Press, pp. 87-125.

Ger, Güliz, and Russell W. Belk. 1995. Cross-cultural differences in materialism. Journal of Economic Psychology 17: 55-77. [CrossRef] 
Gerrish, Brian Albert. 2001. A Prince of the Church: Schleiermacher and the Beginnings of Modern Theology. Eugene: Wipf and Stock Publishers.

Goossaert, Vincent, and David A. Palmer. 2011. The Religious Question in Modern China. Chicago: University of Chicago Press.

Grim, Brian J., and Roger Finke. 2007. Religious persecution in cross-national context: Clashing civilizations or regulated religious economies? American Sociological Review 72: 633-58. [CrossRef]

Hall, David D. 1997. Lived Religion in America: Toward a History of Practice. Princeton: Princeton University Press.

Hanna, Fred J., and Alan Green. 2004. Asian shades of spirituality: Implications for multicultural school counseling. Professional School Counseling 7: 326-33.

Harrell, Stevan. 1977. Modes of belief in Chinese folk religion. Journal for the Scientific Study of Religion 16: 55-65. [CrossRef]

Harrell, Stevan. 1979. The concept of soul in Chinese folk religion. The Journal of Asian Studies 38: 519-28. [CrossRef]

Hill, Peter C., and Kenneth I. Pargament. 2008. Advances in the conceptualization and measurement of religion and spirituality: Implications for physical and mental health research. American Psychologist 58: 64-74. [CrossRef]

Hornell, James. 1944. The ancient village gods of South India. Antiquity 18: 78-87. [CrossRef]

Houtman, Dick, Stef Aupers, and Paul Heelas. 2009. Christian religiosity and new age spirituality: A cross-cultural comparison. Journal for the Scientific Study of Religion 48: 169-79. [CrossRef]

Hsieh, Jiann. 1986. China's nationalities policy: Its development and problems. Anthropos 81: 1-20.

Irwin, Harvey J., and Caroline A. Watt. 2007. An Introduction to Parapsychology, 5th ed. Jefferson: McFarland \& Company, Inc.

James, William. 1977. Conclusions to the varieties of religious experience. In The Writings of William James. Edited by John J. McDermott. Chicago: University of Chicago Press, pp. 758-82. First published 1902.

Ji, Li-Jun, Kaiping Peng, and Richard E. Nisbett. 2000. Culture, control, and perception of relationships in the environment. Journal of Personality and Social Psychology 78: 943-55. [CrossRef]

Ji, Zhe. 2006. Non-institutional religious re-composition among the Chinese youth. Social Compass 53: 535-49. [CrossRef]

Jim, Heather S. L., James E. Pustejovsky, Crystal L. Park, Suzanne C. Danhauer, Allen C. Sherman, George Fitchett, and Thomas V. Merluzzi. 2015. Religion, spirituality, and physical health in cancer patients: A meta-analysis. Cancer 121: 3760-68. [CrossRef]

Johnson, Dan R., and Lauren A. Borden. 2012. Participants at your fingertips: Using Amazon's Mechanical Turk to increase student-faculty collaborative research. Society for the Teaching of Psychology 39: 245-51. [CrossRef]

Kandari, Laxman Singh, Vinod Kumar Bisht, Meenakshi Bhardwaj, and Ashok Kumar Thakur. 2014. Conservation and management of sacred groves, myths and beliefs of tribal communities: A Case study from north-India. Environmental Systems Research 3: 16. [CrossRef]

Kendler, Kenneth S., Charles O. Gardner, and Carol A. Prescott. 1997. Religions, psychopathology, and substance use and abuse; a multi-measure, genetic-epidemiologic study. American Journal of Psychiatry 154: 322-29. [PubMed]

Kendler, Kenneth S., Charles O. Gardner, and Carol A. Prescott. 1999. Clarifying the relationship between religiosity and psychiatric illness: The impact of covariates and the specificity of buffering effects. Twin Research and Human Genetics 2: 137-44. [CrossRef]

Kent, Eliza F. 2013. Sacred Groves and Local Gods: Religion and Environmentalism in South India. New York: Oxford University Press.

Kern, Martin. 2007. Text and Ritual in Early China. Seattle: University of Washington Press.

Kristeller, Jean L., and Kevin D. Jordan. 2017. Spirituality and meditative practice: Research opportunities and challenges. Psychological Studies 63: 1-10. [CrossRef]

Lai, Hongyi Harry. 2005. The religious revival in China. The Copenhagen Journal of Asian Studies 18: 40-64.

Levin, Jeff. 2011. Energy healers: Who they are and what they do. The Journal of Science and Healing 7: 13-26. [CrossRef]

Li, Wai-yee. 1999. Dreams of interpretation in early Chinese historical and philosophical writings. In Dream Cultures: Explorations in the Comparative History of Dreaming. Edited by David Dean Shulman and Guy G. Stroumsa. New York: Oxford University Press, pp. 17-42. 
Liang, Liping. 2012. Multiple variations: Perspectives on the religious psychology of Buddhist and Christian converts in the People's Republic of China. Pastoral Psychology 61: 865-77. [CrossRef]

Lizhu, Fan. 2003. Popular religion in contemporary China. Social Compass 50: 449-57. [CrossRef]

Loh, Jennifer Ung. 2014. Narrating identity: The employment of mythological and literary narratives in identity formation among the Hijras of India. Religion and Gender 4: 21-39. [CrossRef]

Luhrmann, Tanya Marie. 2014. To Dream in Different Cultures. The New York Times. Available online: https://www.nytimes.com/2014/05/14/opinion/luhrmann-to-dream-in-different-cultures.html (accessed on 22 April 2019).

Madsen, Richard. 2011. Religious renaissance in China today. Journal of Current Chinese Affairs 40: 17-42. [CrossRef]

Malhotra, Neil. 2008. Completion time and response order effects in web surveys. Public Opinion Quarterly 72 : 914-34. [CrossRef]

McClintock, Clayton H., Elsa Lau, and Lisa Miller. 2016. Phenotypic dimensions of spirituality: Implications for mental health in China, India, and the United States. Frontiers in Psychology 7: 1600. [CrossRef]

McKinnon, Andrew. 2014. Elementary forms of the metaphorical life: Tropes at work in Durkheim's theory of the religious. Journal of Classical Sociology 14: 203-21. [CrossRef]

Miller, Jon, and Gregory Stanczak. 2009. Redeeming, ruling, and reaping: British missionary societies, the East India company, and the India-to-China opium trade. Journal for the Scientific Study of Religion 48: 332-52. [CrossRef]

Miller, Lisa, Iris M. Balodis, Clayton H. McClintock, Jiansong Xu, Cheryl M. Lacadie, Rajita Sinha, and Marc N. Potenza. 2019. Neural correlates of personalized spiritual experiences. Cerebral Cortex 29: 2331-338. [CrossRef]

Miller, Lisa, Ravi Bansal, Priya Wickramaratne, Xuejun Hao, Craig E. Tenke, Myrna M. Weissman, and Bradley S. Peterson. 2014. Neuroanatomical correlates of religiosity and spirituality: A study in adults at high and low familial risk for depression. JAMA Psychiatry 71: 128-35. [CrossRef]

Moberg, David O. 2002. Assessing and measuring spirituality: Confronting dilemmas of universal and particular evaluative criteria. Journal of Adult Development 9: 47-60. [CrossRef]

Mooney, Brona, and Fiona Timmins. 2007. Spirituality as a universal concept: Student experience of learning about spirituality through the medium of art. Nurse Education in Practice 7: 275-84. [CrossRef]

Muller, Rene J. 2008. Neurotheology: Are we hardwired for god? Psychiatric Times 25: 24.

Newberg, Andrew B., and Stephanie K. Newberg. 2008. Hardwired for god: A neurotheological model for developmental spirituality. In The Search Institute Series on Developmentally Attentive Community and Society (Volume 5). Edited by Kathleen Kovner Kline. New York: Springer.

Newberg, Andrew, Michael Pourdehnad, Abass Alavi, and Eugene G. d'Aquili. 2003. Cerebral blood flow during meditative prayer: Preliminary findings and methodological issues. Perceptual and Motor Skills 97: 625-30. [CrossRef]

Newcombe, Suzanne. 2009. The development of modern yoga: A survey of the field. Religion Compass 3: 986-1002. [CrossRef]

Nickolas, Markos, Alice Hayes, Patricia Hughes, Dean Hammer, Ann Clarke, Kenneth Pargament, and Carrie Doehring. 2009. Perceiving Sacredness in life: Correlates and predictors. Archive for the Psychology of Religion 31: 55-73.

Niebuhr, Richard R. 1964. Schleiermacher on Christ and Religion: A New Introduction. New York: Scribner.

Nisbett, Richard E., and Yuri Miyamoto. 2005. The influence of culture: Holistic versus analytic perception. Trends in Cognitive Sciences 9: 467-73. [CrossRef] [PubMed]

Ong, Roberto K. 1985. The Interpretation of Dreams in Ancient China. Bochum: Seiten.

Otto, Rudolf. 1958. The Idea of the Holy: An Inquiry into the Non-Rational Factor in the Idea of the Divine and Its Relation to the Rational. Translated by John W. Harvey. Oxford: Oxford University Press. First published 1917.

Paden, William E. 1991. Before "the sacred" become theological: Rereading the Durkheimian legacy. Method and Theory in the Study of Religion 3: 10-23. [CrossRef]

Piedmont, Ralph L. 1999. Does spirituality represent the sixth factor of personality? Spiritual transcendence and the five-factor model. Journal of Personality 67: 985-1013. [CrossRef]

Piedmont, Ralph L., and Mark M. Leach. 2002. Cross-cultural generalizability of the spiritual transcendence scale in India: Spirituality as a universal aspect of human experience. American Behavioral Scientist 45: 1888-901. [CrossRef] 
Podoshen, Jeffrey S., Lu Li, and Junfeng Zhang. 2011. Materialism and conspicuous consumption in China: A cross-cultural examination. International Journal of Consumer Studies 35: 17-25. [CrossRef]

Potter, Pitman B. 2003. Belief in control: Regulation of religion in China. The China Quarterly 174: $317-37$. [CrossRef]

Prabhavananda, Swami. 2019. The Spiritual Heritage of India (Vol. 10). London: Routledge.

Preston, Laurence W. 2002. Shrines and neighborhood in early nineteenth-century Pune, India. Journal of Historical Geography 28: 203-15. [CrossRef]

Rambo, Lewis R. 1999. Theories of conversion: Understanding and interpreting religious change. Social Compass 46: 259-71. [CrossRef]

Raphals, Lisa. 2014. Divination and Prediction in Early China and Ancient Greece. Cambridge: Cambridge University Press.

Reinstein, Ellen S. 2004. Turn the other cheek, or demand an eye for an eye? Religious persecution in China and an effective western response. Connecticut Journal of International Law 20: 1.

Reynolds, Larry T., and Nancy J. Herman. 1994. Symbolic Interaction: An Introduction to Social Psychology. Walnut Creek: Altamira Press.

Rican, Pavel, and Pavlina Janosova. 2010. Spirituality as a basic aspect of personality: A cross-cultural verification of Piedmont's model. International Journal for the Psychology of Religion 20: 2-13. [CrossRef]

Rol, Cécile. 2012. Animism and totemism: Durkheim versus Wundt. L'annee Sociologique 62: 351-66. [CrossRef]

Roof, Wade Clark, and William McKinney. 1987. American Mainline Religion: Its Changing Shape and Future. New Brunswick: Rutgers University Press.

Roof, Wade Clark. 2001. Spiritual Marketplace: Baby Boomers and the Remaking of American Religion. Princeton: Princeton University Press.

Ross, Heidi, and Yimin Wang. 2010. The college entrance examination in China: An overview of its social-cultural foundations, existing problems, and consequences. Chinese Education and Society 43: 3-10. [CrossRef]

Rottman, Joshua, Liqi Zhu, Wen Wang, Rebecca Seston Schillaci, Kelly J. Clark, and Deborah Kelemen. 2017. Cultural influences on the teleological stance: Evidence from China. Religion, Brain, E Behavior 7: 17-26.

Roy, Himanshu. 2006. Western secularism and colonial legacy in India. Economic and Political Weekly 41: $158-65$.

Saroglou, Vassilis. 2010. Religiousness as a cultural adaptation of basic traits: A five-factor model perspective. Personality and Social Psychology Review 14: 108-25. [CrossRef]

Sawatzky, Rick, Pamela A. Ratner, and Lyren Chiu. 2005. A meta-analysis of the relationship between spirituality and quality of life. Social Indicators Research 72: 153-88. [CrossRef]

Sax, Linda J., Shannon K. Gilmartin, and Alyssa N. Bryant. 2003. Assessing response rates and nonresponse bias in web and paper surveys. Research in Higher Education 44: 409-32. [CrossRef]

Segal, Robert A. 2012. Clifford Geertz's interpretive approach to religion. Religion Compass 6: 511-24. [CrossRef]

Segall, Marshall H., Donald Thomas Campbell, and Melville Jean Herskovits. 1968. The influence of culture on visual perception. In Social Perception. Indianapolis: Bobbs-Merrill.

Sherkat, Darren E., and John Wilson. 1995. Preferences, constrains, and choices in religious markets: An examination of religious switching and apostasy. Social Forces 73: 993-1026. [CrossRef]

Skaggs, Brenda G., and Cecilia R. Barron. 2006. Searching for meaning in negative events: Concept analysis. Journal of Advanced Nursing 53: 559-70. [CrossRef]

Smith, Christian, and David Sikkink. 2003. Social predictors of retention in and switching from the religious faith of family of origin: Another look using religious tradition self-identification. Review of Religious Research 45: 188-206. [CrossRef]

Squires, Allison, Linda H. Aiken, Koen Van den Heede, Walter Sermeus, Luk Bruyneel, Rikard Lindqvist, and Lisette Schoonhoven. 2013. A systematic survey instrument translation process for multi-country, comparative health workforce studies. International Journal of Nursing Studies 50: 264-73. [CrossRef]

Sutton, Donald S. 2007. Death rites and Chinese culture: Standardization and variation in Ming and Qing times. Modern China 33: 125-53. [CrossRef]

Teiser, Stephen F. 1986. Ghosts and ancestors in medieval Chinese religion: The Yü-lan-p'en festival as mortuary ritual. History of Religions 26: 47-67. [CrossRef]

Thaibourne, Michael A., and Peter S. Delin. 1999. Transliminality: Its relation to dream life, religiosity, and mystical experience. The International Journal for the Psychology of Religion 9: 45-61. [CrossRef] 
Thapar, Romila. 1989. Imagined religious communities? Ancient history and the modern search for a Hindu identity. Modern Asian Studies 23: 209-31. [CrossRef]

Thompson, Laurence G. 1988. Dream, divination and Chinese popular religion. Journal of Chinese Religions 16: 73-82. [CrossRef]

Underwood, Lynn G., and Jeanne A. Teresi. 2002. The daily spiritual experience scale: Development, theoretical description, reliability, exploratory factor analysis, and preliminary construct validity using health-related data. Annals of Behavioral Medicine 24: 22-33. [CrossRef] [PubMed]

Vaismoradi, Mojtaba, Hannele Turunen, and Terese Bondas. 2013. Content analysis and thematic analysis: Implications for conducting a qualitative descriptive study. Nursing $\mathcal{E}$ Health Sciences 15: 398-405.

Van der Veer, Peter. 2009. Spirituality in modern society. Social Research: An International Quarterly 76: 1097-120.

Walsh, Roger. 1989. Can western philosophers understand Asian philosophies? The challenge and opportunity of states-of-consciousness research. CrossCurrents 39: 281-99.

Ward, Barbara E. 1979. Not merely players: Drama, art and ritual in traditional China. Man, New Series 14: 18-39. [CrossRef]

Worsley, Peter M. 1956. Emile Durkheim's theory of knowledge. The Sociological Review 4: 47-62. [CrossRef]

$\mathrm{Yu}$, Lan, and Hoi K. Suen. 2005. Historical and contemporary exam-driven education ever in China. KEDI Journal of Educational Policy 2: 17-33.

Zhang, W., D. Du, and Shuangju Zhen. 2011. Belief systems and positive youth development among Chinese and American youth. Thriving and Spirituality Among Youth: Research Perspectives and Future Possibilities, 309-31.

Zinnbauer, Brian J., Kenneth I. Pargament, and Allie B. Scott. 1999. The emerging meanings of religiousness and spirituality: Problems and prospects. Journal of Personality 67: 889-919. [CrossRef]

(C) 2020 by the authors. Licensee MDPI, Basel, Switzerland. This article is an open access article distributed under the terms and conditions of the Creative Commons Attribution (CC BY) license (http://creativecommons.org/licenses/by/4.0/). 